\title{
Di-Benzo-18-Crown-6 and its Derivatives as Ligands in the Search for Ion Channels
}

\author{
Katharina M. Fromm*, Rémi D. Bergougnant, and Adeline Y. Robin \\ Basel / Switzerland, University, Department of Chemistry
}

Dedicated to Professor Kurt Dehnicke on the Occasion of his $75^{\text {th }}$ Birthday

\begin{abstract}
Based on the previously reported one-dimensional channel system $\left[\left(\mathrm{H}_{2} \mathrm{O}\right) \subset(\mathrm{DB} 18 \mathrm{C} 6)\left(\mu_{2}-\mathrm{H}_{2} \mathrm{O}\right)_{2 / 2}\right]\left[\left(\mathrm{H}_{3} \mathrm{O}\right) \subset(\mathrm{DB} 18 \mathrm{C} 6)\left(\mu_{2}-\right.\right.$ $\left.\left.\mathrm{H}_{2} \mathrm{O}\right)_{2 / 2}\right] \mathrm{I}_{3}$ (2), which is realized by stacking of crown ether molecules (DB18C6 = dibenzo-18-crown-6), other synthetic approaches towards ionic channels and their results are presented in this paper. The "cutting out" approach using DB18C6 as scissor, applied on $\mathrm{NaI}$, yields the compound [NaC(DB18C6)I(THF)]$\left[\mathrm{NaC}(\mathrm{DB} 18 \mathrm{C} 6)\left(\mathrm{H}_{2} \mathrm{O}\right)_{2}\right] \mathrm{I}(\mathrm{THF})_{2}\left(\mathrm{CHI}_{3}\right)(\mathbf{1})$, in high yield. It is based on a neutral and a cationic complex of sodium by DB18C6 linked via $\mathrm{H}$-bonding to give short chain fragments. The anion exchange approach, trying to replace $\mathrm{I}_{3}{ }^{-}$by $\mathrm{Br}_{3}{ }^{-}$leads to the intercalation
\end{abstract}

of a cation into a DB18C6 chain in $\left[\left(\mathrm{Me}_{3} \mathrm{NPh}\right)(\mathrm{DB} 18 \mathrm{C} 6)\right] \mathrm{Br}_{3}(\mathbf{3})$. A similar reaction as for the synthesis of 2 , but replacing iodide with bromine, yields finally a brominated DB18C6 ligand. In the presence of iron, the compound $\left[\left(\mathrm{H}_{5} \mathrm{O}_{2}\right) \subset\left(\mathrm{Br}_{4}-\mathrm{DB} 18 \mathrm{C} 6\right)_{2}\right]\left[\mathrm{FeBr}_{4}\right]$, 4 , is observed, in which a $\mathrm{H}_{5} \mathrm{O}_{2}^{+}$-cation is encapsuled by two brominated crown ether molecules. The absence of $\mathrm{Fe}$ and an excess of $\mathrm{Br}_{2}$ leads to the complexation of $\mathrm{H}_{3} \mathrm{O}^{+}$, and co-crystallisation of bromine in $\left[\left(\mathrm{H}_{3} \mathrm{O}\right) \subset\left(\mathrm{Br}_{4}-\mathrm{DB} 18 \mathrm{C} 6\right)\right] \mathrm{Br}_{3} \mathrm{Br}_{2}$ (5).

Keywords: Alkali metals; Crown ethers; Structure elucidation; Ion channels

\section{Introduction}

Since the pioneering work of Pedersen, crown ethers and their complexes with metal cations have attracted considerable attention [1]. The remarkable selectivity of crown ethers on metal cations, especially alkali and alkaline earth metals cations, is a topic of fundamental interest in coordination chemistry and biochemistry. These macrocyclic ligands are fascinating both because they are able to impose unusual coordination numbers and geometries on metal ions, and because they serve as models for metal ion transport across membranes [2]. They have also been used as very selective separation agents on mixtures of metal ions, and especially the ones with six $\mathrm{O}$ atoms such as 18-crown6, dibenzo-18-crown-6 (DB18C6) and dicyclohexano-18crown-6 are known to form stable complexes with alkali metal salts [3], being some rare examples where neutral organic ligands are able to complex charged metal ions in a very efficient way.

\footnotetext{
* Prof. Dr. K. M. Fromm

University of Basel

Department of Chemistry

Spitalstrasse 31

CH-4056 Basel

Tel.: +41612671004

Fax: +41612671021

E-mail: katharina.fromm@unibas.ch

www.chemie.unibas.ch
}

As we are interested in the formation of new materials with functional properties, especially the lower dimensional polymers [4-7] in order to generate anisotropy, the question arose whether it was possible to stabilize one-dimensional polymers by coordination with crown ether. The potential capacity of dibenzo-crowns to form $\pi$ interactions upon stacking appeared to us as an interesting property in this context. Indeed, we succeeded in the crystallization of a compound in which the dibenzo-18-crown-6 ligands are stacked to yield a channel in which water molecules and $\mathrm{H}_{3} \mathrm{O}^{+}$are present $[8,9]$. We here wish to report on further findings with this ligand, its derivatization and complexation on $\mathrm{Na}^{+}, \mathrm{H}_{3} \mathrm{O}^{+}, \mathrm{H}_{5} \mathrm{O}_{2}{ }^{+}$, and $\left[(\mathrm{Ph}) \mathrm{NMe}_{3}\right]^{+}$as well as packing effects.

\section{Results}

As reported earlier, we are able to chemically "cut out" lowdimensional fragments from a binary three-dimensional network $[5,10]$. In these and other reported structures, we have also shown that iodide can act as very versatile bridging anion [11-17]. In order to "cut out" one-dimensional $\mathrm{NaI}$, a sterically directing ligand, as for instance DB18C6, is required. To test such a reaction, and due to solubility reasons, $\mathrm{NaI}$ is therefore generated in situ by a reaction of $\mathrm{NaO}^{t} \mathrm{Bu}$ with elemental iodine and $\mathrm{DB} 18 \mathrm{C} 6$ in a mixture of THF/ $\mathrm{H}_{2} \mathrm{O}$ /acetone to yield the complex ionic compound $[\mathrm{NaC}(\mathrm{DB} 18 \mathrm{C} 6) \mathrm{I}(\mathrm{THF})]\left[\mathrm{Na} \subset(\mathrm{DB} 18 \mathrm{C} 6)\left(\mathrm{H}_{2} \mathrm{O}\right)_{2}\right] \mathrm{I}(\mathrm{THF})_{2^{-}}$ $\left(\mathrm{CHI}_{3}\right)(\mathbf{1})$ in $80 \%$ yield. 1 crystallizes in the monoclinic 


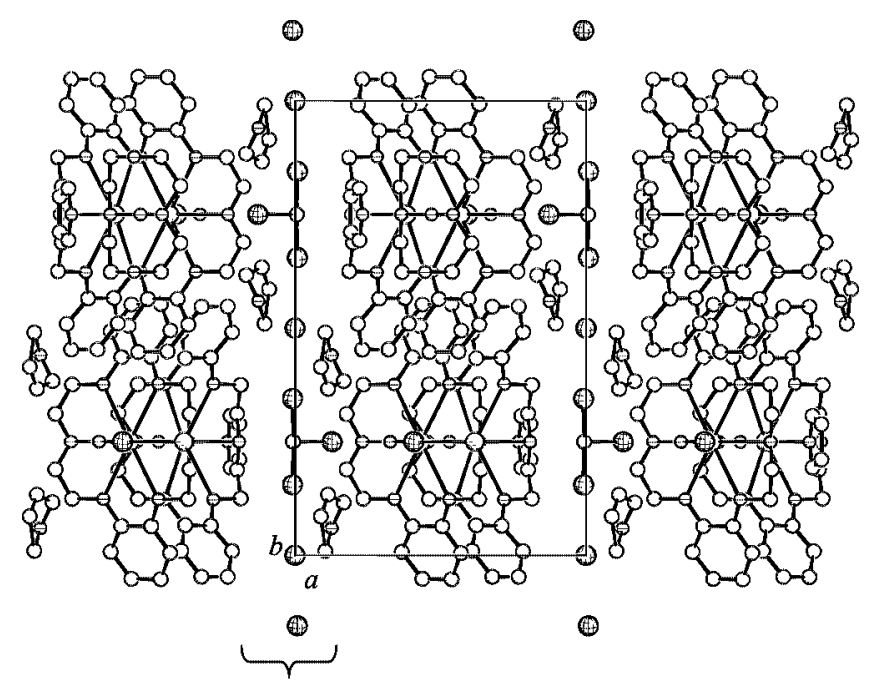

Layer of solvents and 12

Figure 1 View of the packing onto the $a b$-plane of 1, including solvent molecules, but excluding $\mathrm{H}$-atoms for clarity

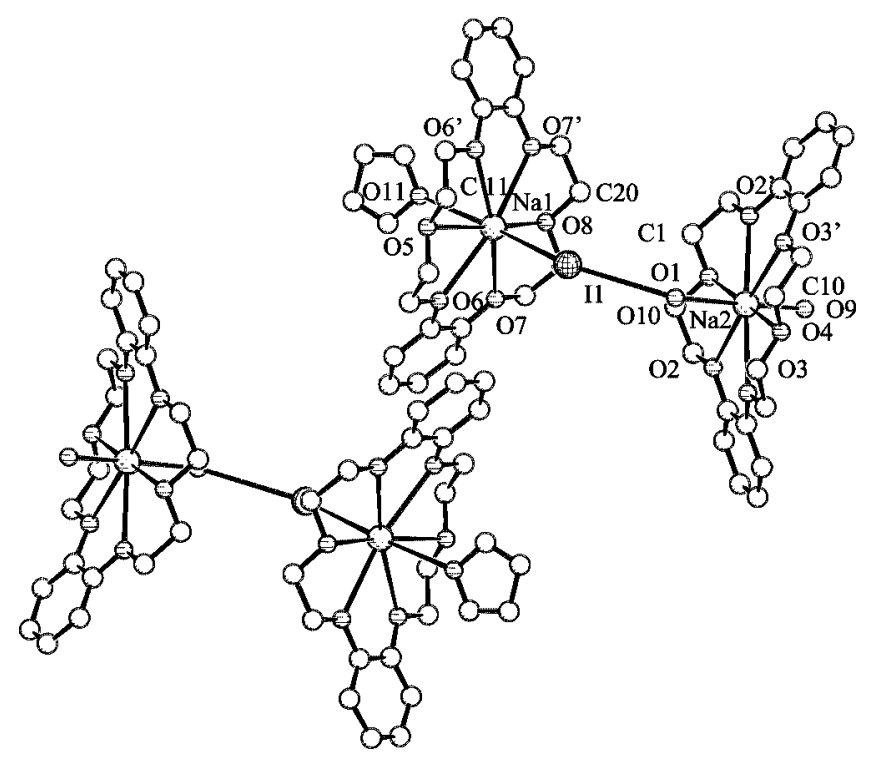

Figure 2 Cationic dimers of $\mathbf{1}$ linked via H-bonding (H-atoms omitted for clarity)

space group $P 2_{1} / \mathrm{m}$ (Nr. 11) with four molecules per unit cell. The cationic complex of $\mathbf{1},\left[\mathrm{Na}(\mathrm{DB} 18 \mathrm{C} 6)\left(\mathrm{H}_{2} \mathrm{O}\right)_{2}\right]^{+}$, consists of a sodium cation to which a DB18C6-ligand in equatorial, and two water molecules in axial positions of a hexagonal bipyramidal coordination sphere are coordinated. The neutral complex in $\mathbf{1}$ is a [NaC(DB18C6)I(THF)] unit (Figures 1 and 2).

The counter ion to the cationic complex is a free iodide ion, I2 which is not directly coordinated to the cation. Furthermore, there are free solvent molecules, two THF and one $\mathrm{CHI}_{3}$ molecules, filling voids in the structure, but not coordinated to the cationic or neutral complexes of $\mathbf{1}$. The $\mathrm{Na}-\mathrm{O}(\mathrm{DB} 18 \mathrm{C} 6)$ distances are between 2.74(1) and
2.778(9) $\AA$ long. This corresponds well to average values observed in the literature [18-20], but is, as expected, longer than in similar complexes with the smaller crown ether $15 \mathrm{C} 5$ [21, 22]. On average, the Na2-O(DB18C6) distances in the complex cation of $\mathbf{1}$ are by $0.03 \AA$ shorter than in the neutral moiety of $\mathbf{1}$. The sodium cation $\mathrm{Na} 2$ is 0.051 (8) $\AA$ out of the mean plane formed by the six surrounding oxygen atoms of the crown ether, slightly exo of the folding of the latter. The phenyl rings of the DB18C6 in the cationic unit form an angle of 133.6(3) ${ }^{\circ}$ towards O10. The two neutral water ligands, $\mathrm{O} 9$ and $\mathrm{O} 10$, act as axial ligands to the sodium cation, with $\mathrm{Na} 2-\mathrm{O}\left(\mathrm{H}_{2} \mathrm{O}\right)$ distances of 2.48(2) (Na2-O10) and 2.14(5) $\AA$ ( Na2-O9). The difference in these distances is due to the fact that one water molecule, $\mathrm{O} 9$, is a terminal ligand, whereas the other, $\mathrm{O} 10$, is linked to the iodide of the neutral unit of $\mathbf{1}$ via H-bonding. In fact, the hydrogen bond to $\mathrm{I} 1$ is of a distance of O10-I1 3.51(3) $\AA$, the Na2-O10-I1 angle being $130(2)^{\circ}$. The Hbonded system between the neutral unit and the cationic complex of $\mathbf{1}$ is shown in Figure 2. I1 is directly coordinating to Na1 with 3.523(4) $\AA$. This is by ca. $0.5 \AA$ longer than in the non-linked, isolated neutral complex [NaC(DB18C6)I(THF)] [18], showing the dramatic elongation effect on the $\mathrm{Na}-\mathrm{I}$ bond by hydrogen bonding. The coordination sphere of $\mathrm{Na} 1$ is completed by one DB18C6 ligand and a terminally bonded THF ligand (Na1-O11 3.00(4) $\AA$ ) opposite I1 to yield an overall neutral complex. The folding of the DB18C6 ligand in the neutral complex of 1 , in the direction of the THF ligand, results in an angle of $125.7(3)^{\circ}$ between the mean planes through the phenyl rings. Even though the folding is directed in the same way as in the neutral literature compound [18], the folding is not as important (ca. $90^{\circ}$ in $[\mathrm{NaC}(\mathrm{DB} 18 \mathrm{C} 6) \mathrm{I}(\mathrm{THF})]$ ).

The arrangement of the crown ether complexes extends in two dimensions, with the sodium ions $\mathrm{Na} 1$ and $\mathrm{Na} 2$, and I1 on the crystallographic sites $(\mathrm{x}, 1 / 4, \mathrm{z}(e))$ which correspond to a mirror plane. In addition to the free anion I2, which is placed on a crystallographic inversion centre $(0,1 / 2,1 / 2(c))$, two disordered THF molecules and a $\mathrm{CHI}_{3}$ molecule co-crystallize in the solid state parallel to the $b c$ plane (Figure 3). I3 of the iodoform is also placed on a crystallographic mirror plane (x, $1 / 4, \mathrm{z}(\mathrm{e}))$. I4 of the iodoform points toward the free anion $\mathrm{I} 2$ at a distance of $3.787(2) \AA$, leading to a linear arrangement of I4, I2 and I4 of a second iodoform molecule within the sheet. The $b c$ plane is thus divided into strands containing iodide ions and iodine atoms of iodoform, and chains containing the THF molecules. The sheets containing solvent molecules and counter ions alternate with the planes containing the crown ether complexes (Figure 1).

The presence of iodoform, which was not added as a solvent, can be explained when looking at the reaction conditions. In a first step, $\mathrm{NaO}^{t} \mathrm{Bu}$ is hydrolysed in the THF/ $\mathrm{H}_{2} \mathrm{O}$ mixture to yield $\mathrm{NaOH}$ and $\mathrm{HO}^{t} \mathrm{Bu}$. The latter can be oxidized under weakly basic conditions to acetone by iodine, which itself is reduced to iodide. In addition to this fact, acetone has also been deliberately added to the solvent 


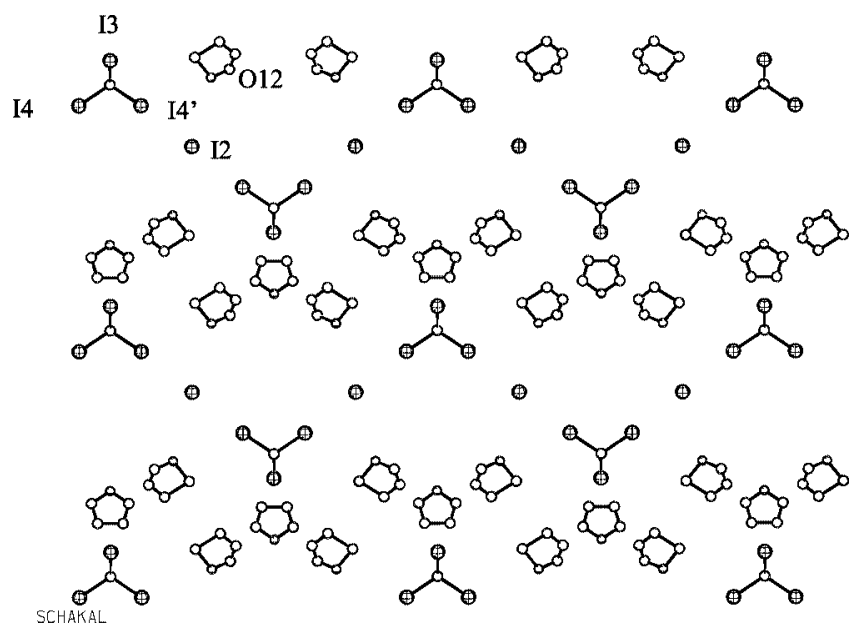

Figure 3 Layer of solvent and counter ions contained in 1 showing the arrangement of $\mathrm{HCI}_{3}$ and $\mathrm{I}_{2}, \mathrm{H}$-atoms omitted

mixture, and it reacts typically with excess iodine under basic conditions to yield $\mathrm{CHI}_{3}$ and byproducts (iodoform reaction) [23].

In compound 1, a fragment of a chain structure is achieved by hydrogen bonding, which does not completely propagate in one dimension, but is stopped by terminal THF ligands to sodium. If THF was not present in compound 1, a structure similar to the known $\left[\mathrm{NaC}(\mathrm{DB} 18 \mathrm{C} 6) \mathrm{Br}\left(\mathrm{H}_{2} \mathrm{O}\right)\right]\left[\mathrm{NaC}(\mathrm{DB} 18 \mathrm{C} 6)\left(\mathrm{H}_{2} \mathrm{O}\right)_{2}\right] \mathrm{Br}\left(\mathrm{H}_{2} \mathrm{O}\right)$ [24], with an infinite one-dimensional hydrogen bonding system would possibly have been observed. A comparison of the fragments $[\mathrm{NaC}(\mathrm{DB} 18 \mathrm{C} 6) \mathrm{I}(\mathrm{THF})]$ and $\left[\mathrm{NaC}(\mathrm{DB} 18 \mathrm{C} 6)\left(\mathrm{H}_{2} \mathrm{O}\right)_{2}\right]^{+}$with analogues in the literature shows that the distances fit in general with previous results $[18,24,25]$. The distance Na1-I1 with 3.523(4) $\AA$ of $\mathbf{1}$, is longer than in the structure [NaC(DB18C6)I(THF)] [18], where Na-I is 3.094(3) $\AA$. The average Na-O(crown ether) distances in $\mathbf{1}$ are with 2.738(7) and 2.766(7) $\AA$ longer than in $\left[\mathrm{NaC}(\mathrm{DB} 18 \mathrm{C} 6)\left(\mathrm{H}_{2} \mathrm{O}\right)_{2}\right]^{+}$in which a dimer of a cationic complex is observed with average $\mathrm{Na}-\mathrm{O}$ (crown ether) distances of 2.705 and $2.727 \AA$ [24]. In the latter compound, the $\mathrm{Na}-\mathrm{O}$ distance to the terminal water molecule is with 2.313(9) $\AA$ by $0.7 \AA$ shorter than the Na-O(THF) distance in $\mathbf{1}$, but by ca. $0.2 \AA$ longer than for the similar $\mathrm{Na}-\mathrm{O}\left(\mathrm{H}_{2} \mathrm{O}\right)$ bond of $\mathbf{1}$.

In our previously published channel system, $\left[\left(\mathrm{H}_{2} \mathrm{O}\right) \subset(\mathrm{DB} 18 \mathrm{C} 6)\left(\mu_{2}-\mathrm{H}_{2} \mathrm{O}\right)_{2 / 2}\right]\left[\left(\mathrm{H}_{3} \mathrm{O}\right) \subset(\mathrm{DB} 18 \mathrm{C} 6)\left(\mu_{2^{-}}\right.\right.$ $\left.\left.\mathrm{H}_{2} \mathrm{O}\right)_{2 / 2}\right]_{3}$ (2) [8], the synthesis of $\mathbf{2}$ was modified so that $\mathbf{2}$ can be obtained from an aqueous solution of DB18C6, iodine and HI. As DB18C6 molecules rarely stack in the solid state as seen in the few examples where it does [8, 9, 26, 27] compared to the huge number of described structures where it doesn't, we suggested that $\mathrm{I}_{3}{ }^{-}$as linear anion could be structure directing and helpful in the arrangement of onedimensional arrays, as seen in $\mathbf{2}$. We therefore attempted to use other linear anions, such as $\mathrm{SCN}^{-}$or $\mathrm{Br}_{3}{ }^{-}$, with the aim of making similar channel systems. Whereas reactions using thiocyanate as counter anion so far only yielded

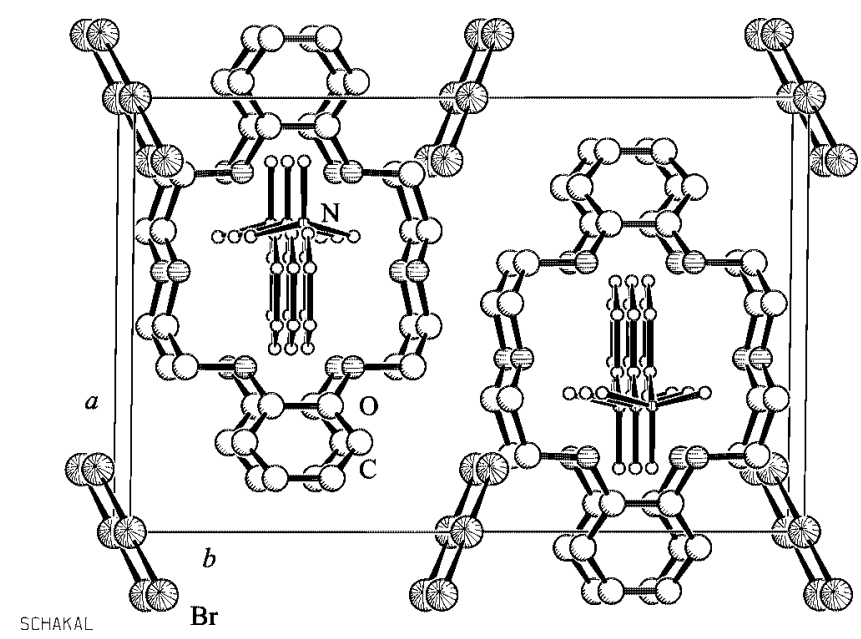

Figure 4 View of a unit cell ( $b c$-plane) of 3, showing parallel arrangement of crown ether molecules, $\mathrm{H}$-atoms omitted for clarity

known compounds, such as $[\mathrm{NaC}(\mathrm{DB} 18 \mathrm{C} 6)(\mathrm{SCN})(\mathrm{THF})]$ [28], or $\left[\mathrm{NaC}(\mathrm{DB} 18 \mathrm{C} 6)\left(\mathrm{H}_{2} \mathrm{O}\right)_{2}\right]\left[\mathrm{NaC}(\mathrm{DB} 18 \mathrm{C} 6)(\mathrm{SCN})_{2}\right]$ [29], the reactions using bromine and tribromide yielded some new insights into crown ether chemistry.

In a first reaction, a tribromide was used, and a large cation, phenyl trimethyl ammonium, was chosen in order to avoid a possible cation complexation by the crown ether ligand. Straightforward, the compound $\left[\left(\mathrm{Me}_{3} \mathrm{NPh}\right)(\mathrm{DB} 18 \mathrm{C} 6)\right] \mathrm{Br}_{3}$ (3), is obtained in $90 \%$ yield, crystallizing in the monoclinic space group $P 2_{1} / \mathrm{m}$ (Nr.11) with two molecules per unit cell. Indeed, the cation of $\mathbf{3}$, $\left[\mathrm{Me}_{3} \mathrm{NPh}\right]^{+}$is not strongly coordinated by the crown ether, and the DB18C6 molecules are stacked to form channels in the direction of the $b$-axis (Figure 4). The stacking is however not a close one as in $\mathbf{2}$, as the large $\left[\mathrm{Me}_{3} \mathrm{NPh}\right]^{+}$cations are intercalated between the DB18C6 ligands with the phenyl group pointing in the direction of the middle of one DB18C6 molecule, and the methyl groups pointing opposite into the cavity formed by the next DB18C6 ring (Figure 5). A crystallographic mirror plane runs through the carbon atoms of the phenyl ring of the cation, its nitrogen atom and a methyl group, all placed on $(\mathrm{x}, 1 / 4, \mathrm{z},(e))$. Hydrogen bonds are observed between cation and crown ether, the shortest one being formed from hydrogen on a methyl group, H18A, to O1 of the crown ether with 2.534(1) $\AA$. Another short contact is found between $\mathrm{H} 12$ of the phenyl ring of $\left[\mathrm{Me}_{3} \mathrm{NPh}\right]^{+}$and $\mathrm{O} 1$ of the next macrocycle with 2.572(1) $\AA$. The crown ether molecules are in a folded "butterfly" configuration with angles between the two phenyl rings of $106.8(2)^{\circ}$. This is ca. $10^{\circ}$ wider than the angles observed in 2 [8], but by ca. $20^{\circ}$ smaller than in $\mathbf{1}$. The direction of folding of the crown ethers alters from one channel to the next, adopting the opposite direction. The distance between two DB18C6 molecules within one channel corresponds to $9.520 \AA$ (the length of the $a$-axis). The tribromide anions are linear due to an inversion centre on which $\mathrm{Br} 1$ is placed $(0,0,0(a))$, and possess $\mathrm{Br} 1-\mathrm{Br} 2$ and $\mathrm{Br} 1-\mathrm{Br}^{\prime}$ distances of $2.5454(6) \AA$. They do not run parallel to the 


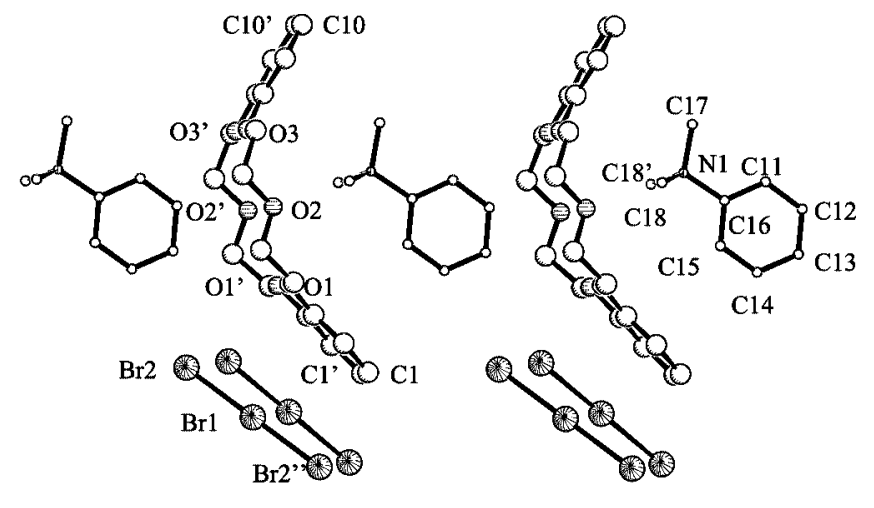

SEHAKAL.

Figure 5 Intercalation of large cations between parallel DB18C6 ligands in $\mathbf{3}$ (H-atoms omitted for clarity)

channel propagation direction, but are inclined by $40.48^{\circ}$ with respect to the $a$-axis.

Attempting to generate tribromide in situ, reaction conditions were chosen similar to the ones necessary for generating $\mathbf{2}$. Thus, bromine was added to a solution of DB18C6 in THF in the presence of water and iron. The compound $\left[\left(\mathrm{H}_{5} \mathrm{O}_{2}\right) \subset\left(\mathrm{Br}_{4}-\mathrm{DB} 18 \mathrm{C} 6\right)_{2}\right]\left[\mathrm{FeBr}_{4}\right](4)$, is observed in $60 \%$ yield. It crystallizes in the monoclinic space group $C 2 / \mathrm{c}$ (Nr.15) with four molecules per unit cell. Its formation can be explained by a series of reactions. In a first step, the crown ether molecule is twice brominated at each of the two phenyl groups to yield $4^{\prime}, 5^{\prime}, 4^{\prime \prime}, 5^{\prime \prime}$-tetrabromodibenzo-18crown-6 (furtheron called " $\mathrm{Br}_{4}$-DB18C6") [30-32], and $\mathrm{HBr}$. The latter generates acidic conditions necessary for the presence of $\mathrm{H}_{3} \mathrm{O}^{+}$. Present iron powder is attacked and oxidized by bromine to give the large $\left[\mathrm{FeBr}_{4}\right]^{-}$anion present in the structure of $\mathbf{4}$. The iron atom of the anion is placed on a crystallographic two-fold axis $(0, \mathrm{y}, 0.25(e))$. The huge cationic complex of $\mathbf{4}, \quad\left[\left(\mathrm{H}_{5} \mathrm{O}_{2}\right) \subset\left(\mathrm{Br}_{4-}\right.\right.$ DB18C6) $\left.{ }_{2}\right]^{+}$, is formed by two $\mathrm{Br}_{4}$-DB18C6 ligands that confine a tennisball-like cavity with a corresponding seam (Figures 6 and 7). In the center of this cavity, two oxygen atoms, $\mathrm{O} 7$ and its symmetry equivalent $\mathrm{O}^{\prime}$ are found. $\mathrm{O} 7$ is located 1.36(1) $\AA$ over the mean plane formed by the six oxygen atoms of the crown ether, and the $\mathrm{O} 7-\mathrm{O}$ (crown) distances are rather long and range from 2.84(1) $\AA$ (with O5) to $3.26(1) \AA$ (with O1). The shorter ones probably correspond to hydrogen bonding interactions. Hydrogen atoms could not all be located on $\mathrm{O} 7$, only two could be attributed, pointing in the direction of $\mathrm{O} 5 / \mathrm{O} 4$ and $\mathrm{O} 2 / \mathrm{O} 3$, indicating bifurcating $\mathrm{H}$-bonding. But the $\mathrm{O} 7-\mathrm{O}^{\prime}$ ' distance of 2.42(2) $\AA$ indicates that the present species is a $\mathrm{H}_{5} \mathrm{O}_{2}{ }^{+}$cation stabilized in this cavity with the third proton being split over two positions somewhere along the bisector between $\mathrm{O} 7$ and $\mathrm{O}^{\prime}$. Crystallographically, this means that a water molecule and a hydronium cation are delocalized over both positions, respectively that the third hydrogen atom could be delocalized over both oxygen atoms. In the IR spectrum of 4, typical broad bands for $\mathrm{H}_{5} \mathrm{O}_{2}{ }^{+}$, respectively $\mathrm{H}_{3} \mathrm{O}^{+} / \mathrm{H}_{2} \mathrm{O}$ are found at $3359 \mathrm{~cm}^{-1}$ and around $1700 \mathrm{~cm}^{-1}$.

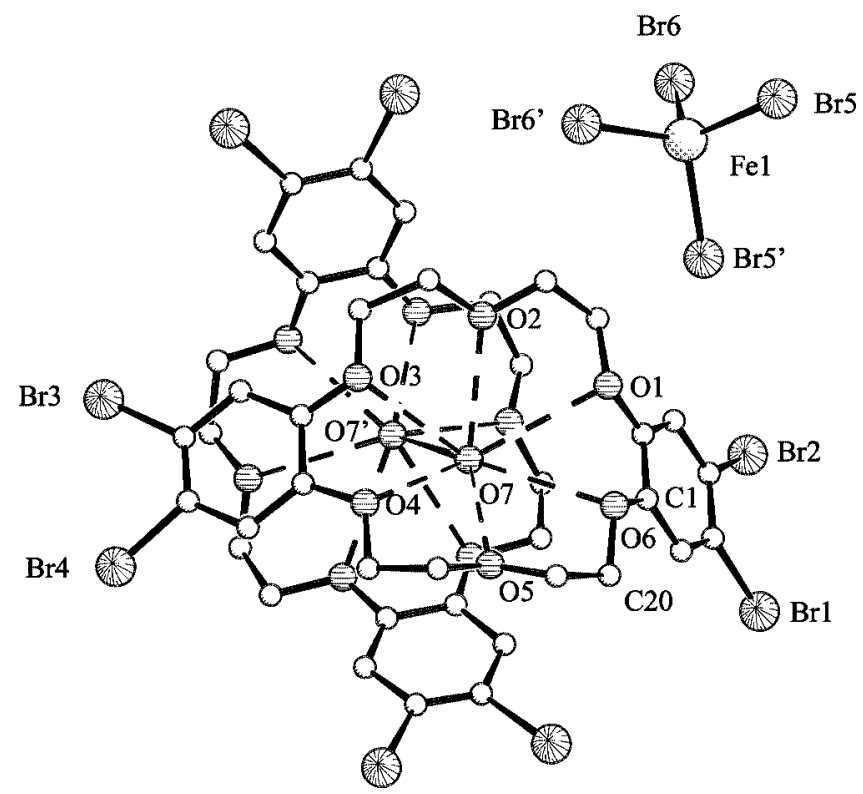

Figure 6 Molecular entity of 4, H-atoms omitted for clarity

Similar distances and IR bands are observed in other structures in which $\mathrm{H}_{5} \mathrm{O}_{2}{ }^{+}$has been characterized, and compared to literature compounds, the O7-O7' distance of $\mathbf{4}$ is in the range of normal O-O contacts $(2.288 \AA$ to $2.473 \AA$ ) for $\mathrm{H}_{5} \mathrm{O}_{2}{ }^{+}[33,34]$. The dibromo substituted phenyl rings of one crown ether molecule form an angle of 127.4(7) ${ }^{\circ}$ to each other, which is on average wider than in the nonbrominated DB18C6, however, the latter can also adopt flatter angles in some cases, as seen for instance in 1. Interestingly, one of the phenyl rings is only deviated by $15.6(3)^{\circ}$ from the mean plane formed by the six oxygen atoms of the crown ether whereas the other is $48.8(2)^{\circ}$ out of plane. This is probably due to the fact that two macrocylces embrace each other in such a way that one of the phenyl rings is flattened towards the mean plane of the ring oxygen atoms whereas the other is more deviated.

In the packing of $\mathbf{4}$, the "tennis balls" arrange along the $c$-axis, and bromine atoms of the ligand as well as from the $\left[\mathrm{FeBr}_{4}\right]^{-}$point into channels along the same direction (Figure 8). Hydrogen bonds between the four bromine atoms of $\left[\mathrm{FeBr}_{4}\right]^{-}$and $\mathrm{H}$-atoms of crown ether phenyl rings are observed around $3 \AA$ and imply $\mathrm{Br} 5-\mathrm{H} 5$ and $\mathrm{Br} 6-\mathrm{H} 2$. One bromine atom of each phenyl ring, $\mathrm{Br} 1$ and $\mathrm{Br} 4$, is also involved in hydrogen bonding to $\mathrm{H} 9 \mathrm{~A}$ and $\mathrm{H} 20 \mathrm{~A}$, respectively (3.02 and $3.25 \AA$ ) of neighbor crown ether molecules. Shorter contacts of bromine with hydrogen atoms are present in the structure, but cannot be counted as efficient $\mathrm{H}$ bonding due to small $\mathrm{C}-\mathrm{Br}-\mathrm{H}$ angles $<90^{\circ}$.

The NMR signals of $\mathbf{4}$ are complicated to interpret due to the similitude of $\mathrm{H}_{3} \mathrm{O}^{+}$and $\mathrm{H}_{5} \mathrm{O}_{2}{ }^{+}$. In 4 , a signal at $7.704 \mathrm{ppm}$ seems to testify the presence of $\mathrm{H}_{5} \mathrm{O}_{2}{ }^{+}$. Two other signals at $3.747 \mathrm{ppm}$ and $1.444 \mathrm{ppm}$ could reveal the dissociation of $\mathrm{H}_{5} \mathrm{O}_{2}{ }^{+}$in $\mathrm{H}_{3} \mathrm{O}^{+}$and $\mathrm{H}_{2} \mathrm{O}$ when crystals are dissolved in $\mathrm{CDCl}_{3}$. Further analysis, with COESY and HSDQC, reveal the interaction of $\mathrm{H} 7 \mathrm{a}$ with $\mathrm{H} 17 \mathrm{a}, \mathrm{H} 10 \mathrm{~b}$ 


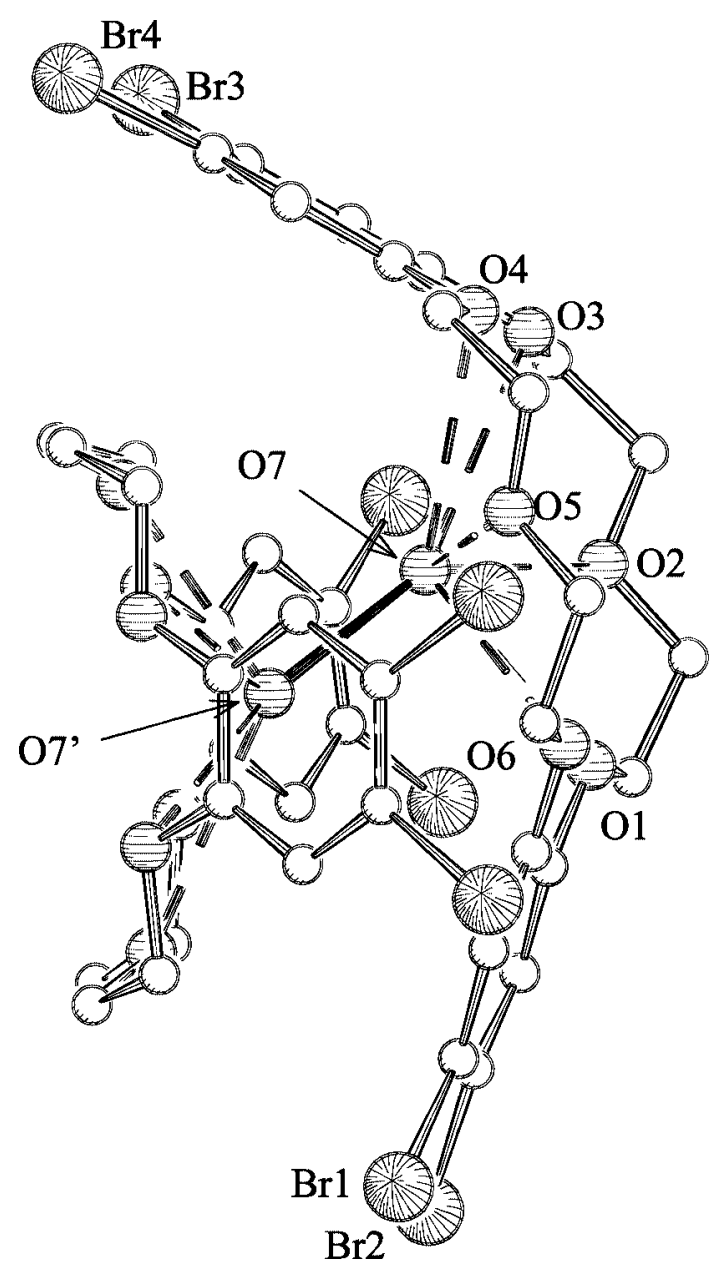

Figure 7 Side-view of the capsule formed by two $\mathrm{Br}_{4}$-DB18C6 ligands, containing $\mathrm{H}_{5} \mathrm{O}_{2}{ }^{+}$

(H-atoms omitted for clarity)

with $\mathrm{H} 10 \mathrm{~b}$ and $\mathrm{H} 20 \mathrm{~b}$ with $\mathrm{H} 20 \mathrm{~b}(\mathrm{CH} 2)$ from one crown ether with their homologues on the partner crown ether in the bowl. This indicates that the tennis-ball shaped capsule exists partially also in solution.

The same reaction carried out as for $\mathbf{4}$ with bromine in excess, but without iron present, yields the compound $\left[\left(\mathrm{H}_{3} \mathrm{O}\right) \subset\left(\mathrm{Br}_{4}-\mathrm{DB} 18 \mathrm{C} 6\right)\right] \mathrm{Br}_{3} \mathrm{Br}_{2}(\mathbf{5})$, crystallizing in the triclinic space group $P-1$ with two molecules per unit cell. Again the DB18C6 has been brominated to yield the $\mathrm{Br}_{4^{-}}$ DB18C6 (Fig. 9). The ionic compound 5 consists of a complex cation in which $\mathrm{H}_{3} \mathrm{O}^{+}(\mathrm{O} 7)$ is coordinated by the six oxygen atoms of a $\mathrm{Br}_{4}$-DB18C6. The $\mathrm{O} 7$ atom is by $0.32(1) \AA$ out of the mean plane formed by the six oxygen atoms of the macrocycle on the exo position to the cavity, indicating pyramidal $\mathrm{H}_{3} \mathrm{O}^{+}$as discussed previously $[8,25$, 35], with $\mathrm{O} 7-\mathrm{O}$ (crown) distances between 2.54(1) $\AA$ to O5 and 2.80(1) $\AA$ to O2. This large difference in distances shows the asymmetric coordination of $\mathrm{H}_{3} \mathrm{O}^{+}$by the crown ether. Hydrogen atoms of the cation could be located in the Fourier map. They are arranged in a pyramidal fashion around $\mathrm{O} 7$, two hydrogen atoms pointing towards $\mathrm{O} 5$ and

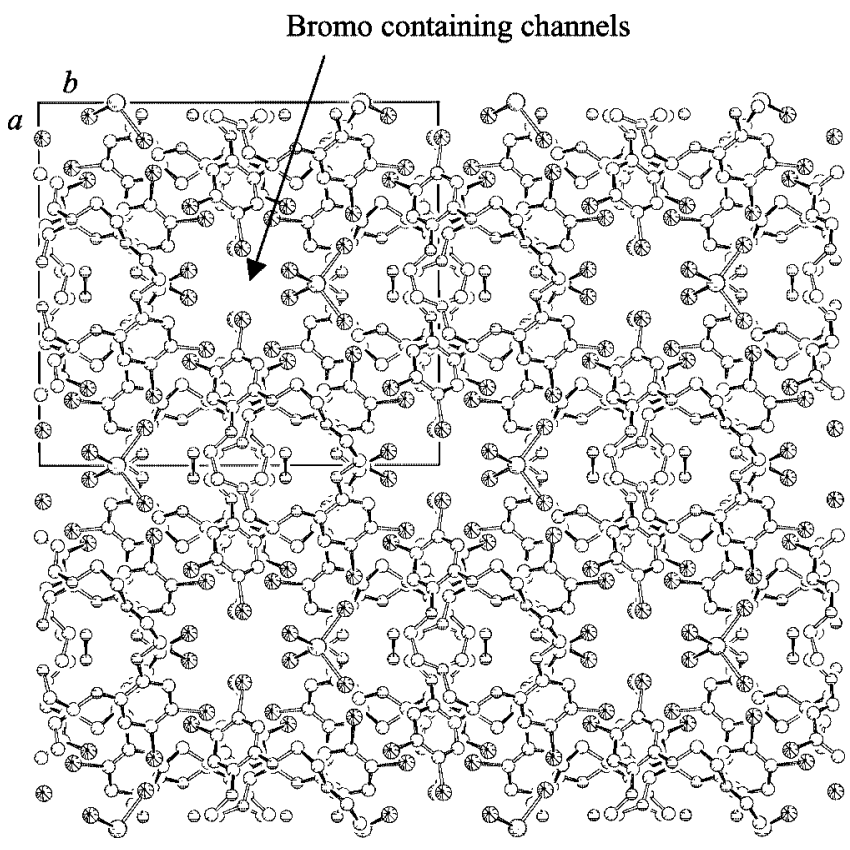

Figure 8 Packing of $\mathbf{4}$ to yield bromo-containing channels (ab-plane) (H-atoms omitted for clarity)

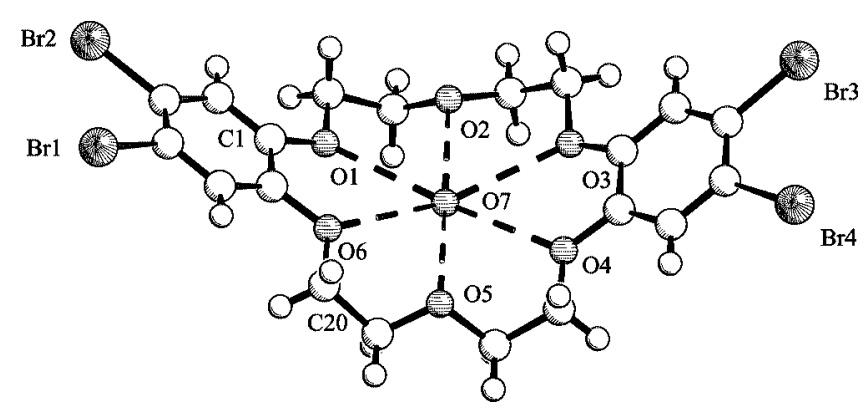

Figure 9 cationic complex of 5

O3 with a strong $\mathrm{H}$-bond of 1.6(1) $\AA$ for $\mathrm{H} 71-\mathrm{O} 5$ $\left(\mathrm{O} 7-\mathrm{H} 71-\mathrm{O} 5163(8)^{\circ}\right)$, and a weaker H-bond of 2.0(1) $\AA$ for $\mathrm{H} 72-\mathrm{O} 3\left(\mathrm{O} 7-\mathrm{H} 72-\mathrm{O} 3\right.$ of $\left.143(9)^{\circ}\right)$. The distances between $\mathrm{O}$ (crown ether) and $\mathrm{O} 7$ varying from 2.557(2) to 2.81(1) $\AA$ are on average similar to the values in structures with 18 crown6 $[36,37]$ varying from $2.55(5)$ to $2.84(5) \AA$ or with DB18C6 [38], varying from 2.570(7) to 2.797(8) A. The disorder observed in the structure by Reich et al. seems to be absent in $\mathbf{5}$ [38]. The third hydrogen atom of $\mathrm{H}_{3} \mathrm{O}^{+}$does not point to an oxygen atom of the crown ether, but to $\mathrm{Br} 3$ of an adjacent crown ether molecule, with a distance of $3.103 \AA$. Indeed, it seems that $\mathrm{Br} 3$ points more in the direction of the crown below than the other three close bromine atoms attached to adjacent crown ether molecules. The two phenyl rings form an angle of 120.9(2) to each other, by ca. $7^{\circ}$ smaller than in $\mathbf{4}$, and exclude the hydronium cation. This time, and in contrast to $\mathbf{4}$, both phenyl rings are almost equally out of the mean plane formed by the six oxygen atoms of the crown ether, i. e. by ca $30^{\circ}$. 


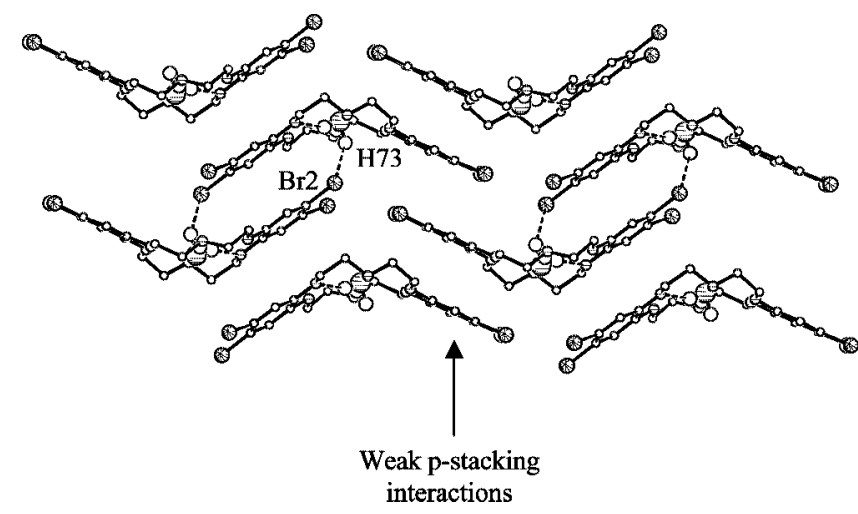

Figure 10 packing of cationic complexes in 5 (H-atoms omitted for clarity)
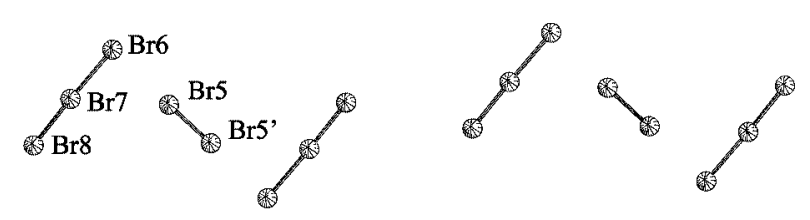
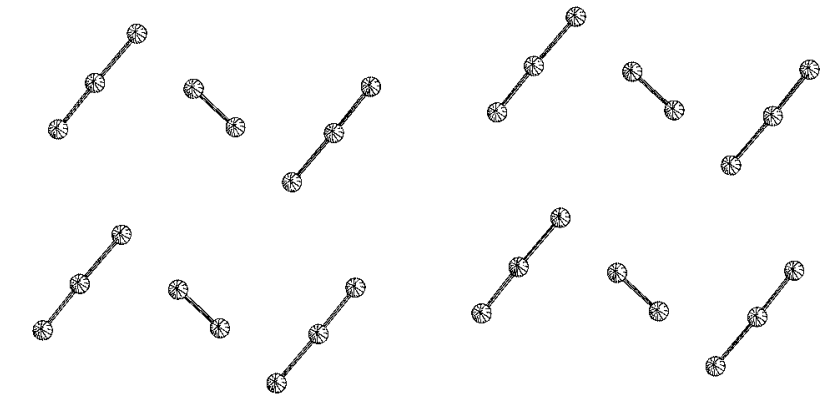

SCHAKAL

Figure 11 Layer of 5 containing counter ions $\mathrm{Br}_{3}{ }^{-}$and $\mathrm{Br}_{2}$ molecules

The so formed cations stack on top of each other, all folded in the same direction within one stack, and by $8.138 \AA$ apart from each other. The neighbor stack of cations runs in the opposite direction and intercalates with the dibromo-phenyl groups between the dibromo phenyl groups of crown ether molecules of the first stack (Figure 10). The aromatic rings are offset to each other by ca. $4.7 \AA$ and are closest to each other at ca. $3.7 \AA$, indicating only very weak $\pi$-interactions. The arrangement is such that sheets of cations are formed in the $(\mathrm{x}, 1 / 4, \mathrm{z})$-plane. The two-dimensional cationic arrays are separated by the anions, consisting of $\mathrm{Br}_{3}{ }^{-}$, and by bromine, $\mathrm{Br}_{2}$. Bromine and tri- bromide are arranged in a plane (Figure 12). The $\mathrm{Br}-\mathrm{Br}$ distance in $\mathrm{Br}_{2}$ is 2.331(3) $\AA$ long, whereas in the tribromide, the distances are 2.401(3) and 2.627(2) $\AA$ for Br7-Br8, respectively $\mathrm{Br} 6-\mathrm{Br} 7$. The $\mathrm{Br} 6-\mathrm{Br} 7-\mathrm{Br} 8$ angle is almost linear at $177.6(5)^{\circ}$. Weak interactions between the tribromide and bromine can be considered at a distance Br6-Br5 of 3.187(2) $\AA$. A crystallographic inversion centre is found in the middle of the bromine molecule. The short $\mathrm{Br}-\mathrm{Br}$ distances of $\mathbf{5}$ are by $0.02 \AA$ longer than the shortest one in solid bromine [39]. The longer interbromine contacts are in the range of normal $\mathrm{Br}-\mathrm{Br}$ found for polybromide ions [40, 41].

The signal at $3.74 \mathrm{ppm}$ found in the NMR spectrum of $\mathbf{4}$ is also present in the one of $\mathbf{5}$. This value is more or less in accordance with the signal of $4.33 \mathrm{ppm}$ given by You and al. [42] for $\mathrm{H}_{3} \mathrm{O}^{+}$. The difference could result from a change in the environment. Indeed in $\mathbf{4}$ and $\mathbf{5}$, hydronium ions are isolated from the environment by coordination with crown ether.

\section{Discussion}

The compounds $\mathbf{1 - 5}$ present the different types of organisation of crown ether molecules. $\mathbf{1}$ is a combination of two defined complexes found in the literature: $[\mathrm{Na} \subset(\mathrm{DB} 18 \mathrm{C6}) \mathrm{I}(\mathrm{THF})]$ and $\left[\mathrm{Na} \subset(\mathrm{DB} 18 \mathrm{C} 6)\left(\mathrm{H}_{2} \mathrm{O}\right)_{2}\right]^{+}$. In fact, it is interesting to notice the difference between a bridging and a non-bridging iodide ion upon the coordination of the crown ether ligand toward $\mathrm{Na}^{+}$. In $\mathbf{1}$, coordination is assumed principally by $\mathrm{O} 5$ of the crown ether ligand whereas some weaker interactions exist with other oxygen atoms of the crown ether. Table 1 and scheme 1 compare the coordination of $\mathrm{Na}^{+}$by DB18C6 in our and other literature compounds. In most cases, the $\mathrm{Na}-\mathrm{O}$ distances are distributed asymmetrically around the crown ether ligand, with the shortest and the longest bonds being separated by one medium long $\mathrm{Na}-\mathrm{O}$ contact.

The crown ether molecules in $\mathbf{1}$ seem to be arranged by serendipity. The introduction of a cation as bridging agent favors the apparition of well-organized chains of crown ether ligands like in $\mathbf{3}$. These chains are maintained by hydrogen bonds. Finally, if the cation is small and capable of $\mathrm{H}$-bonding, infinite $\pi$-stacking of the crown ether molecules like in $\mathbf{2}$ can be observed. In this last eventuality, small cations have to be linked by a small molecule in order to allow close packing of the macrocyclic ligands $\left(\mathrm{H}_{2} \mathrm{O}\right.$ in 2 , acetonitrile in reference [42]). In the absence of an efficient linker,

Table 1 Comparison of average distances in $\mathbf{1}$ and similar literature compounds

\begin{tabular}{|c|c|c|c|c|c|c|}
\hline Interatomic distances & $\begin{array}{l}{[\mathrm{Na} \subset(\mathrm{DB} 18 \mathrm{C} 6) \mathrm{I}-} \\
(\mathrm{THF})] \text { in } \mathbf{1} \\
\text { A }\end{array}$ & $\begin{array}{l}{\left[\mathrm{Na} \subset(\mathrm{DB} 18 \mathrm{C} 6) \mathrm{Br}\left(\mathrm{H}_{2} \mathrm{O}\right)\right]} \\
\text { in infinite chain }[24] \\
\text { B }\end{array}$ & $\begin{array}{l}{[\mathrm{Na} \subset(\mathrm{DB} 18 \mathrm{C} 6) \mathrm{I}-} \\
(\mathrm{THF})] \text { in }[19] \\
\mathbf{C}\end{array}$ & & $\begin{array}{l}{[\mathrm{Na} \subset(\mathrm{DB} 18 \mathrm{C} 6)-} \\
\left.\left(\mathrm{H}_{2} \mathrm{O}\right)_{2}\right]+ \text { in } \mathbf{1} \\
\mathbf{D}\end{array}$ & $\begin{array}{l}{\left[\mathrm{Na} \subset(\mathrm{DB} 18 \mathrm{C} 6)\left(\mathrm{H}_{2} \mathrm{O}\right)_{2}\right]+} \\
\text { in infinite chain }[24] \\
\mathbf{E}\end{array}$ \\
\hline $\mathrm{Na}-\mathrm{O}$ (crown ether)shorter & $2.747(6)$ & $2.54(1)$ & $2.612(8)$ & Na-O shorter & $2.723(7)$ & $2.63(1)$ \\
\hline $\mathrm{Na}-\mathrm{O}$ (crown ether) larger & $2.777(6)$ & $2.89(1)$ & $2.777(7)$ & Na-O larger & $2.740(7)$ & $2.82(1)$ \\
\hline $\mathrm{Na}-\mathrm{O}$ (ligand) & $3.00(4)$ & $2.35(1)$ & $2.302(7)$ & $\mathrm{Na}-\mathrm{O}$ (water) & $2.14(4)$ & $2.31(2)$ \\
\hline $\mathrm{Na}-\mathrm{X}$ & $3.523(4)$ & $2.82(1)$ & $3.094(3)$ & $\mathrm{Na}-\mathrm{O}$ (water) & $2.54(3)$ & $2.27(1)$ \\
\hline
\end{tabular}



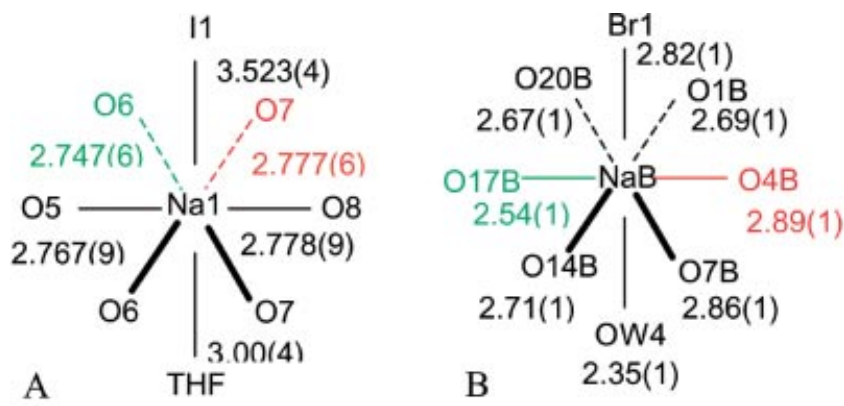

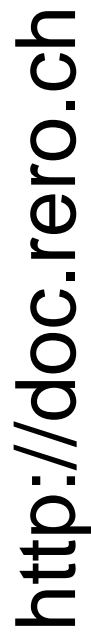

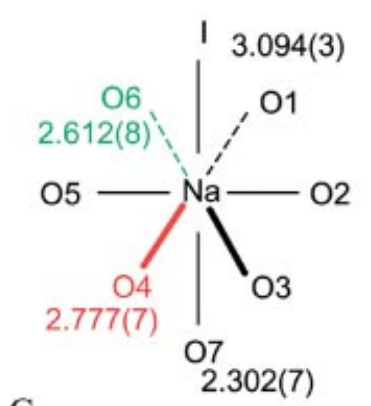

C
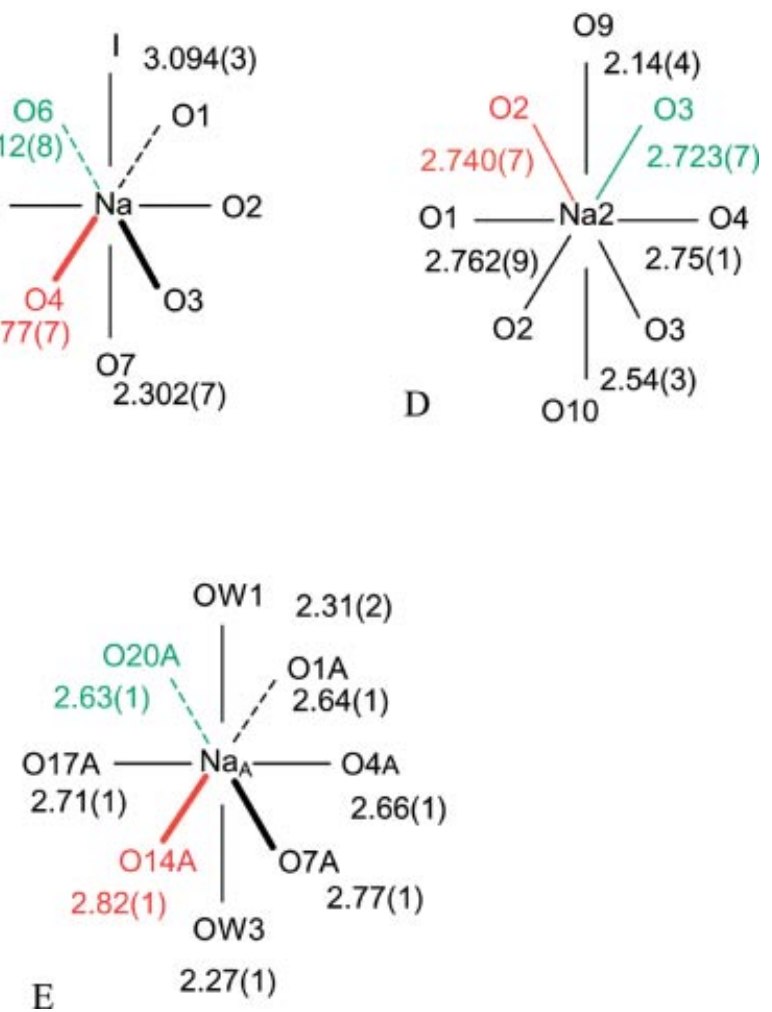

Scheme 1 Schematic representation of the coordination of $\mathrm{Na}^{+}$ by DB18C6

only one single $\pi$-stacking is observed by the crown ether ligands as in $\mathbf{5}$, or as in the structure published by Kloo et al. [26]. $\left[\left(\mathrm{H}_{3} \mathrm{O}\right) \subset\left(\mathrm{Br}_{4}-\mathrm{DB} 18 \mathrm{C} 6\right)\right] \mathrm{Br}_{3} \mathrm{Br}_{2}$ (5), shows the same organization of the crown ether ligands as in compound $\left[\left(\mathrm{H}_{3} \mathrm{O}\right) \subset(\mathrm{DB} 18 \mathrm{C} 6) \mathrm{I}_{3}\right][26]$. The main difference lies in the presence of bromine molecules, which limits the symmetry operations in the crystal, whereas tribromide and triiodide are pointing in the same direction along the intertwined crown ether stacks. In table 2, the environment of $\mathrm{H}_{3} \mathrm{O}^{+}$for 5 and the literature compound is summed up. In comparison with the structure described by Kloo, the distances are the same for the longer coordination bonds of $\mathrm{H}_{3} \mathrm{O}^{+}$. For the shorter distance, there is a difference of $0.13 \AA$ which can be attributed to a better stabilization of $\mathrm{H}_{3} \mathrm{O}^{+}$in $\mathbf{5}$.

Finally, crown ethers are able to create capsules around dihydronium like in $\mathbf{5}$ or around purinium [43]. For small guests, crown ethers are able to build a cage similar to the
Table 2

\begin{tabular}{lll}
\hline Interatomic distances & {$\left[\left(\mathrm{H}_{3} \mathrm{O}\right) \subset\left(\mathrm{Br}_{4}-\mathrm{DB} 18 \mathrm{C} 6\right)\right]-$} & {$\left[\mathrm{H}_{3} \mathrm{O}(\mathrm{DB} 18 \mathrm{C} 6) \mathrm{I}_{3}\right]$} \\
& $\mathrm{Br}_{3} \mathrm{Br}_{2} \mathbf{5}$ & {$[26]$} \\
\hline $\mathrm{H}_{3} \mathrm{O}^{+}-\mathrm{O}$ (crown ether)shortest & $2.56(1)$ & 2.69 \\
$\mathrm{H}_{3} \mathrm{O}^{+}-\mathrm{O}$ (crown ether) long & $2.81(1)$ & 2.81 \\
$\mathrm{H}_{3} \mathrm{O}^{+}$-plane & $0.35(1)$ & $0.061-0.78$ \\
\hline
\end{tabular}

form of a tennis ball with a corresponding seam. The two crown ether molecules are arranged approximately perpendicular to each other. Cohesion is assured by hydrogen bonds between ethyl hydrogen atoms and ether oxygen atoms (H20a-O5, H17a-O6) as well as phenyl hydrogen atoms and ether oxygen atoms of opposite macrocycles (H15-O1). For larger guests, crown ethers may stack parallel to each other either via weak interactions ( $\pi$-stacking and hydrogen bonds [43]) or due to symmetry as in $\mathbf{3}$.

\section{Conclusions}

We have shown that attempts to generate new channel systems based on DB18C6 and its derivates are not successful when the "cutting out" principle is used for instance on NaI. Although we did not succeed in forming an infinite one-dimensional network, H-bonding yields a fragment of a one-dimensional zig-zag chain in 1. Exchanging the linear anion $\mathrm{I}_{3}{ }^{-}$in a known channel system 2 by other linear anions like $\mathrm{SCN}^{-}$leads to the formation of known compounds. Substitution of $\mathrm{I}_{3}{ }^{-}$by $\mathrm{Br}_{3}{ }^{-}$seems in principle possible, but a large cation is now inserted between the parallel stacked crown ether molecules, omitting the channel character of the structure in 3 . In situ generation of $\mathrm{Br}_{3}{ }^{-}$ with $\mathrm{Br}_{2}$ results in a bromination reaction of the DB18C6 ligand, the resulting product of which is able to encapsulate $\mathrm{H}_{5} \mathrm{O}_{2}{ }^{+}$in $\mathbf{4}$, or $\mathrm{H}_{3} \mathrm{O}^{+}$in 5 .

\section{Experimental Section}

All chemicals were bought from Acros Organics and were used as such. Solvents were not dried before use, and the reactions were carried out in air and at room temperature. IR spectra were recorded on a Shimadzu FTIR-8400S (equipped with a golden gate ATR system), NMR spectra on a Bruker $250 \mathrm{MHz}$ and a Bruker $600 \mathrm{MHz}$. Mass spectra turned out to be difficult to obtain due to decomposition of material. Similar problems occurred for elemental analysis, especially due to the high content of halide and polyhalide, which turned out to easily pollute both machines due to decomposition reactions.

Synthesis of 1: $0.3478 \mathrm{~g}(3.66 \mathrm{mmol})$ of $\mathrm{NaO}^{t} \mathrm{Bu}$ are slowly added

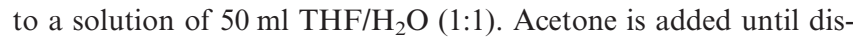
appearance of the interface. $10 \mathrm{ml}$ of a diiode solution $0.1 \mathrm{M}$ ( $1 \mathrm{mmol})$ are added. Finally,0.3824 $\mathrm{g}(1.061 \mathrm{mmol})$ of dibenzo-18crown-6-ether are dissolved in this solution. After $12 \mathrm{~h}$, we observed the growth of needle-like crystals. Yield: $1.510 \mathrm{~g}$ $(0.938 \mathrm{mmol}, 88 \%)$

IR $/ \mathrm{cm}^{-1}: v=3064(\mathrm{w}), v=2948(\mathrm{w}), v=2874(\mathrm{w}), v=1595(\mathrm{~m}), v=$ $1508(\mathrm{~m}), v=1452(\mathrm{~m}), v=1418(\mathrm{w}), v=1392(\mathrm{w}), v=1368(\mathrm{w}), v=$ 
$1330(\mathrm{~m}), v=1291(\mathrm{w}), v=1254(\mathrm{~s}), \mathrm{v}=1228(\mathrm{~s}), \mathrm{v}=1127(\mathrm{~s}), \mathrm{v}=1117$ $(\mathrm{s}), v=1079(\mathrm{~m}), v=1027(\mathrm{~m}), v=993(\mathrm{~s}), v=931(\mathrm{~s}), v=841(\mathrm{w}), v=$ $820(\mathrm{~m}), v=777(\mathrm{~m}), \delta=749(\mathrm{~s}), \delta=737(\mathrm{~s}), \delta=727(\mathrm{~s}) .{ }^{\mathbf{1}} \mathbf{H} \mathbf{~ N M R} \mathbf{~} \mathbf{C D C l}_{\mathbf{3}}$, $250 \mathrm{MHz}): \delta=6.871(\mathrm{~d}, 8 \mathrm{H}, \mathrm{ArH}), \delta=4.144\left(\mathrm{~d}, 16 \mathrm{H}, \mathrm{CH}_{2}\right), \delta=4.784(\mathrm{~s}$ $\left.\mathrm{H}, \mathrm{CHI}_{3}\right), \delta=4.737\left(\mathrm{~m}, 2 \mathrm{H}, \mathrm{H}_{2} \mathrm{O}\right.$ free) $, \delta=3.744\left(\mathrm{~m}, 4 \mathrm{H}, \mathrm{CH}_{2} \mathrm{THF}\right), \delta=$ $1.718\left(\mathrm{~m}, 4 \mathrm{H}, \mathrm{CH}_{2} \mathrm{THF}\right), \delta=1.250\left(\mathrm{~s}, 2 \mathrm{H}, \mathrm{H}_{2} \mathrm{O}\right)$.

Synthesis of 3: $0.1080 \mathrm{~g}(0.299 \mathrm{mmol})$ of dibenzo-18-crown-6-ether and $0.2007 \mathrm{~g}(0.536 \mathrm{mmol})$ of phenyltrimethylammonium tribromide are dissolved in $10 \mathrm{ml}$ of THF. After two weeks, we observed the growth of needle-like crystals. Yield: $0.182 \mathrm{~g}(0.247 \mathrm{mmol}, 82 \%)$ IR $/ \mathrm{cm}^{-1}: v=3411$ (w, broad), $v=2952(\mathrm{~m}), v=2906(\mathrm{~m}), v=2864(\mathrm{~m})$ $v=1639(\mathrm{w}), v=1600(\mathrm{~s}), v=1566(\mathrm{~m}), \mathrm{v}=1494(\mathrm{~s}), \mathrm{v}=1353(\mathrm{~s}), \delta=$ $1249(\mathrm{~m}), \delta=1197(\mathrm{~m}), \mathrm{v}=1134(\mathrm{w}), \mathrm{v}=1120(\mathrm{w}), \mathrm{v}=1089(\mathrm{~m}), \mathrm{v}=$ $1062(\mathrm{~m}), v=1043(\mathrm{~m}), v=952(\mathrm{~s}), \mathrm{v}=844(\mathrm{~m}), \delta=761(\mathrm{~m}), \mathrm{v}=658$ (m). ${ }^{1} \mathbf{H}$ NMR $\left(\mathbf{C D C l}_{3}, \mathbf{2 5 0} \mathbf{M H z}\right): \delta=7.816(\mathrm{~d}, 2 \mathrm{H}, \mathrm{ArH}), \delta=7.704(\mathrm{~m}$ $3 \mathrm{H}, \mathrm{ArH}), \delta=7.140$ to $7.031(\mathrm{~m}, 8 \mathrm{H}, \mathrm{ArH}), \delta=4.090\left(\mathrm{~m}, 4 \mathrm{H}, \mathrm{CH}_{2}\right), \delta=$ $3.983\left(\mathrm{~m}, 4 \mathrm{H}, \mathrm{CH}_{2}\right), \delta=3.928\left(\mathrm{~s}, 9 \mathrm{H},\left(\mathrm{CH}_{3}\right)_{3}\right), \delta=3.570\left(\mathrm{~m}, 8 \mathrm{H}, \mathrm{CH}_{2}\right)$.

Synthesis of 4: 4,4',5,5'-tetrabromodibenzo-18-crown-6-ether is prepared as follows: $1 \mathrm{~g}(2.77 \mathrm{mmol})$ of dibenzo-18-crown- 6 is dissolved in $20 \mathrm{ml}$ THF in a Teflon beaker. $0.215 \mathrm{~g}(3.85 \mathrm{mmol})$ of iron are added to this solution. An excess of $2 \mathrm{ml}(38.919 \mathrm{mmol})$ of bromine is added. This mixture is stirred for $12 \mathrm{~h}$. After evaporation of THF in air, the white solid is washed with water and filtered to yield $1.353 \mathrm{~g}(2.00 \mathrm{mmol}, 72 \%)$.

${ }^{1} \mathrm{H}$ NMR $\left(\mathrm{CDCl}_{3}, 250 \mathrm{MHz}\right): \delta=7.704\left(\mathrm{~s}, 5 \mathrm{H}, \mathrm{H}_{5} \mathrm{O}_{2}{ }^{+}\right), \delta=7.036(\mathrm{~s}, 4 \mathrm{H}$ $\mathrm{ArH}), \delta=4.105\left(\mathrm{~s}, 8 \mathrm{H}, \mathrm{CH}_{2}\right), \delta=3.967\left(\mathrm{~s}, 8 \mathrm{H}, \mathrm{CH}_{2}\right), \delta=3.747(\mathrm{~s}, 3 \mathrm{H}$, $\left.\mathrm{H}_{3} \mathrm{O}^{+}\right), \delta=1.928\left(\mathrm{~s}, \mathrm{H}_{2} \mathrm{O}\right)$.

$0.182 \mathrm{~g}(0.269 \mathrm{mmol})$ of $4,4^{\prime}, 5,5^{\prime}$-tetrabromodibenzo-18-crown-6ether are dissolved in $20 \mathrm{ml}$ THF in a Teflon beaker. $0.0215 \mathrm{~g}$ $(0.385 \mathrm{mmol})$ of iron are added to this solution. Finally, $1 \mathrm{ml}$ of bromine $(19.459 \mathrm{mmol})$ is slowly added. After two weeks, we observed the growth of needle-like crystals. Yield: $0.160 \mathrm{~g}$ $(0.150 \mathrm{mmol}, 56 \%)$

IR $/ \mathrm{cm}^{-1}: v=3359(\mathrm{~m}$, broad $), v=2921(\mathrm{~m}), v=2866(\mathrm{~m}), v=1668(\mathrm{~m})$, $v=1583(\mathrm{~m}), \mathrm{v}=1492(\mathrm{~s}), \mathrm{v}=1444(\mathrm{~s}), \mathrm{v}=1352(\mathrm{~s}), \mathrm{v}=1321(\mathrm{~m}), \delta=$ $1244(\mathrm{~s}), \delta=1195(\mathrm{~s}), \delta=1116(\mathrm{~s}), v=1062(\mathrm{~s}), v=1043(\mathrm{~s}), v=950(\mathrm{~s})$ $\delta=860(\mathrm{~m}), \delta=800(\mathrm{~s}), v=649(\mathrm{~s}) .{ }^{\mathbf{1}} \mathbf{H} \mathbf{~ N M R}\left(\mathbf{C D C l}_{3}, \mathbf{2 5 0} \mathbf{M H z}\right): \delta=$ $7.021(\mathrm{~s}, 4 \mathrm{H}, \mathrm{ArH}), \delta=4.087\left(\mathrm{~s}, 8 \mathrm{H}, \mathrm{CH}_{2}\right), \delta=3.975\left(\mathrm{~s}, 8 \mathrm{H}, \mathrm{CH}_{2}\right), \delta=$ $3.747\left(\mathrm{~s}, 3 \mathrm{H}, \mathrm{H}_{3} \mathrm{O}^{+}\right), \delta=1.600\left(\mathrm{~s}, \mathrm{H}_{2} \mathrm{O}\right)$

Synthesis of 5: $0.186 \mathrm{~g}(0.275 \mathrm{mmol})$ of $4,4^{\prime}, 5,5^{\prime}$-tetrabromodibenzo-18-crown-6-ether are dissolved in $10 \mathrm{ml}$ THF in a Teflon beaker. $0.5 \mathrm{ml}(9.73 \mathrm{mmol})$ of bromine are slowly added. After two weeks, we observed the growth of needle-like crystals. Yield: $0.182 \mathrm{~g}$ $(0.167 \mathrm{mmol}, 61 \%)$

IR $/ \mathrm{cm}^{-1}: v=3350(\mathrm{~m}$, bright $), v=2921(\mathrm{~m}), v=2867(\mathrm{~m}), \mathrm{v}=1668(\mathrm{~m})$ $v=1583(\mathrm{~m}), v=1494(\mathrm{~s}), v=1444(\mathrm{~s}), \mathrm{v}=1352(\mathrm{~s}), \mathrm{v}=1323(\mathrm{~m}), \delta=$ $1245(\mathrm{~s}), \delta=1239(\mathrm{~s}), \delta=1114(\mathrm{~s}), \mathrm{v}=1062(\mathrm{~s}), \mathrm{v}=1045(\mathrm{~s}), \mathrm{v}=948(\mathrm{~s})$ $\delta=914(\mathrm{~m}), \delta=877(\mathrm{~s}), v=858(\mathrm{~s}), \delta=802(\mathrm{~m}), \mathrm{v}=649(\mathrm{~s}) .{ }^{1} \mathbf{H}$ NMR $\left(\mathbf{C D C l}_{3}, 250 \mathrm{MHz}\right): \delta=7.016(\mathrm{~s}, 4 \mathrm{H}, \mathrm{ArH}), \delta=4.093\left(\mathrm{~s}, 8 \mathrm{H}, \mathrm{CH}_{2}\right), \delta=$ $3.972\left(\mathrm{~s}, 8 \mathrm{H}, \mathrm{CH}_{2}\right), \delta=1.604\left(\mathrm{~s}, \mathrm{H}_{2} \mathrm{O}\right)$

\section{Crystallographic details}

Single crystal data for 1: $\mathrm{C}_{53} \mathrm{H}_{77} \mathrm{I}_{5} \mathrm{Na}_{2} \mathrm{O}_{17}, M=1666.67 \mathrm{~g} . \mathrm{mol}^{-1}$, monoclinic, space group $P 2_{1} / \mathrm{m}$ (No. 11), $a=13.760(3), b=$ 19.021(3), $c=14.297(3) \AA, \beta=117.723(1)^{\circ}, V=3312.3(1) \AA^{3}, Z=$ $4, T=243 \mathrm{~K}, D_{\text {calcd }}=1.642 \mathrm{Mg} \cdot \mathrm{m}^{-3}, \mu\left(\mathrm{Mo}_{\mathrm{K} \alpha}\right)=2.420 \mathrm{~mm}^{-1}$, 40217 reflections of which 11814 unique and observed, 367 parameters refined, $R($ int $)=0.0788, R 1=\Sigma\left|F_{o}-F_{c}\right| / \Sigma F_{o}=0.1076, w R 2=$ 0.3129 for $I>2 \sigma$ and $R 1=0.1574, w R 2=0.3625$ for all data, $\mathrm{GooF}=1.016$.

Single crystal data for 3: $\mathrm{C}_{29} \mathrm{H}_{38} \mathrm{Br}_{3} \mathrm{NO}_{6}, M=736.33$ g.mol ${ }^{-1}$, orthorhombic, space group $P 2{ }_{1} / \mathrm{m}$ (No. 11), $a=9.5196(9), b=$
16.124(2), $c=10.8074(1) \AA, \beta=106.457(8)^{\circ}, V=1590.9(3) \AA^{3}$, $Z=2, T=243 \mathrm{~K}, D_{\text {calcd. }}=1.537 \mathrm{Mg} \cdot \mathrm{m}^{-3}, \mu\left(\mathrm{Mo}_{\mathrm{K \alpha} \alpha}\right)=$ $2.141 \mathrm{~mm}^{-1}, 12906$ reflections of which 3572 unique and observed, 190 parameters refined, $R($ int $)=0.1113, R 1=\Sigma\left|F_{o}-F_{c}\right| / \Sigma F_{o}=$ $0.0515, w R 2=0.0864$ for $I>2 \sigma$ and $R 1=0.1141, w R 2=0.1057$ for all data, GooF $=0.997$.

Single crystal data for 4: $\mathrm{C}_{40} \mathrm{H}_{45} \mathrm{Br}_{12} \mathrm{O}_{7} \mathrm{Fe}, M=1764.47 \mathrm{~g} \cdot \mathrm{mol}^{-1}$, monoclinic, space group $C 2 / \mathrm{c}($ No. 15$), a=19.819(2), b=$ $19.269(2), c=16.491(2) \AA, \beta=117.968(5)^{\circ}, V=5562.0(8) \AA^{3}$, $Z=8, T=243 \mathrm{~K}, D_{\text {calcd. }}=2.101 \mathrm{Mg} \cdot \mathrm{m}^{-3}, \mu\left(\mathrm{Mo}_{\mathrm{K} \alpha}\right)=$ $2.141 \mathrm{~mm}^{-1}, 19093$ reflections of which 6049 unique and observed, 303 parameters refined, $R($ int $)=0.1333, R 1=\Sigma\left|F_{o}-F_{c}\right| / \Sigma F_{o}=$ $0.1003, w R 2=0.2577$ for $I>2 \sigma$ and $R 1=0.1599, w R 2=0.3089$ for all data, GooF $=0.961$.

Single crystal data for 5: $\mathrm{C}_{20} \mathrm{H}_{23} \mathrm{Br}_{9} \mathrm{O}_{7}, M=1094.53$ g.mol ${ }^{-1}$, triclinic, space group $P-1$ (No. 2), $a=8.138(1), b=13.076(2), c=$

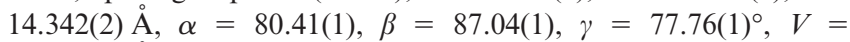
1470.4(4) $\AA^{3}, Z=2, T=243 \mathrm{~K}, D_{\text {calcd. }}=2.292 \mathrm{Mg} \cdot \mathrm{m}^{-3}, \mu$ $\left(\mathrm{Mo}_{\mathrm{K} \alpha}\right)=2.141 \mathrm{~mm}^{-1}, 11849$ reflections of which 6049 unique and observed, 328 parameters refined, $R$ (int) $=0.0878, R 1=\Sigma \mid F_{o^{-}}$ $F_{c} \mid / \Sigma F_{o}=0.0729, w R 2=0.1780$ for $I>2 \sigma$ and $R 1=0.1380$, $w R 2=0.2145$ for all data, $\mathrm{GooF}=1.035$.

Crystals of 1, 3, 4 and $\mathbf{5}$ were measured on an STOE IPDS-II with graphite monochromated Mo- $\mathrm{K}_{\alpha}$ radiation and an Oxford Cryosystems open flow cryostat [44] on a crystal of $0.12 \times 0.1 \times 0.06 \mathrm{~mm}$, and with an absorption correction by analytical integration. [45] The structure was solved with direct methods and refined by full matrix least squares on $F^{2}$ with the SHELX-97 package. [46] All non-hydrogen atoms were refined with anisotropic displacement parameters. The hydrogen atoms were placed in geometrically calculated positions and refined using a riding model. Not all hydrogen atoms for $\mathrm{H}_{5} \mathrm{O}_{2}{ }^{+}, \mathrm{H}_{3} \mathrm{O}^{+}$and $\mathrm{H}_{2} \mathrm{O}$ could be found in the Fourier map and were thus not modelled, their positions being ambiguous. Crystallographic data for structures $\mathbf{1 , 3}, \mathbf{4}$ and $\mathbf{5}$ have been deposited with the Cambridge Crystallographic Data Centre as supplementary publication no. CCDC-291159 (1), CCDC-291160 (3), CCDC-291161 (4) and CCDC-291162 (5). These data can be obtained free of charge via www.ccdc.cam.ac.uk/conts/retrieving.html (or from the Cambridge Crystallographic Data Centre, 12 Union Road, Cambridge CB2 1EZ, UK; fax: (+44)1223-336-033; or deposit@ccdc.cam.ac.uk).

Acknowledgement. The Swiss National Science Foundation SNF is thanked for most generous support in form of a research professorship.

\section{References}

[1] C. J. Pedersen, J. Am. Chem. Soc. 1967, 89, 7017-7036.

[2] R. Boulatov, B. Du, E. A. Meyers, S. G. Shore, Inorg. Chem. 1999, 38, 4554-4558 and literature cited therein.

[3] C. J. Pedersen, H. K. Frensdorff, Angew. Chem. 1972, 84, 16-25; Angew. Chem. Int. Edit. Engl. 1972, 11, 16-25; H.-J. Buschmann, G. Wenz, E. Schollmeyer, Inorg. Chem. Comm. 2001, 4, 53-56.

[4] K. M. Fromm, D. G. Kurth, J.-M. Lehn, Eur. J. Inorg. Chem. 2001, 1523-1526.

[5] K. M. Fromm, Angew. Chem. 1997, 109, 2876-2878; Angew. Chem. Int. Ed. Engl. 1997, 36, 2799-2801. 
[6] K. M. Fromm, G. Bernardinelli, H. Goesmann, M.-J. MayorLopez, J. Weber, Z. Anorg. Allg. Chem. 2000, 7, 1685-1691.

[7] K. M. Fromm, G. Bernardinelli, H. Goesmann, Polyhedron 2000, 19, 1783-1789.

[8] K. M. Fromm, E. D. Gueneau, H. Goesmann, C. Bochet, Z. Anorg. Allg. Chem. 2003, 629, 597-600

[9] M. Dulak, R. Bergougnant, K. M. Fromm, H. R. Hagemann, A. Y. Robin, T. A. Wesolowski, accepted in Spectrochimica Acta Part A: Molecular and Biomolecular Spectroscopy

[10] K. M. Fromm, G. Bernardinelli, Z. Anorg. Allg. Chem. 2001, 627, 1626-1630.

[11] K. M. Fromm, Chem. Eur. J. 2001, 7, 2236-2244.

[12] K. M. Fromm, Chimia 2002, 56, 676-680.

[13] K. M. Fromm, E. D. Gueneau, G. Bernardinelli, H. Goesmann, J. Weber, M.-J. Mayor-López, P. Boulet, H. Chermette, J. Am. Chem. Soc. 2003, 125, 3593-3604.

[14] K. M. Fromm, Chimia 2003, 57, 175-178.

[15] K. M. Fromm, W. Maudez, Eur. J. Inorg. Chem. 2003, 18, $3440-3444$.

[16] K. M. Fromm, E. D. Gueneau, A. Y. Robin, W. Maudez, J. Sague, R. Bergougnant, Z. Anorg. Allg. Chem. 2005, 631, 1725-1740.

[17] K. M. Fromm, E. D. Gueneau, Polyhedron 2004, 23, 1479-1504.

[18] K. M. Fromm, E. D. Gueneau, J.-P. Rivera, G. Bernardinelli, H. Goesmann, Z. Anorg. Allg. Chem. 2002, 628, 171-178.

[19] M. K. Cooper, P. A. Duckworth, K. Henrick, M. McPartlin, J. Chem. Soc. Dalton Trans. 1981, 2357-2364.

[20] D. J. Darensbourg, C. G. Bacu, A. L. Rheingold, Inorg. Chem. 1987, 26, 977-980.

[21] G. W. Buchanan, M. Gerzain, C. Bensimon, Acta Crystallogr. 1994, C50, 1016-1019.

[22] M. A. Bush, M. R. Truter, J. Chem. Soc. Perkin II 1972, $341-344$.

[23] „Advanced Organic Chemistry“, Jerry March, 3 ${ }^{\text {rd }}$ Edition 1985, p.567, Wiley, New York.

[24] M. A. Bush, M. R. Truter, J. Chem. Soc. (B) 1971, $1440-1445$.

[25] H. Zhang, X. Wang, B. K. Teo, J. Am. Chem. Soc. 1996, 118, 11813-11821.

[26] L. Kloo, P. H. Svensson, M. J. Taylor, J. Chem. Soc., Dalton Trans. 2000, 1061-1065.
[27] S. Rashid, S. S. Turner, P. Day, M. E. Light, M. B. Hursthouse, S. Firth, R. J. H. Clark, Chem. Commun. 2001, 1462-1463.

[28] A. Rodrigue, J. W. Bovenkamp, B. V. Lacroix, R. Bannard, Can. J. Chem. 1986, 64, 808-815.

[29] D. Z. Zhu, X. M. Song, J. M. Dou, Y. Liu, D. Q. Wang, Chin. J. Chem. 2002, 20, 424-426.

[30] Z. Karimov, S. A. Talipov, A. K. Tashmukhamedova, M. Idris Saleh, B. T. Ibragimov, T. F. Aripov, Dokl. Akad. Nauk Resp. Uzbekistan 2000, 10, 33-35.

[31] E. Shchori, J. Jagur-Grodzinski, Israel. J.Chem. 1972, 10 , 959-961.

[32] 935-40; G. Dubois, C. Reye, R. J. P. Corriu, C. Chuit, J. Mat. Chem. 2000, 10, 1091-1098.

[33] R. D. Rogers, A. H. Bond, W. G. Hipple, A. N. Rollins, R. F. Henry, Inorg. Chem. 1991, 30, 2671-2679.

[34] A. Hammerschmidt, S, Bonmann, M. Läge, B. Krebs, Z. Anorg. Allg. Chem. 2004, 630, 2035-2041.

[35] A. Alvanipour, J. L. Atwood, S. G. Bott, P. C. Junk, U. H. Kynast, H. Prinz, J. Chem. Soc., Dalton Trans. 1998, $1223-1228$.

[36] J.-P. Behr, P. Dumas, D. Moras, J. Am. Chem. Soc. 1982, 104, 4540-4543.

[37] J. L. Atwood, S. G. Bott, P. C. Junk, M. T. May, J. Organomet. Chem. 1995, 487, 7-15.

[38] O. Reich, S. Hasche, S. Bonmann, B. Krebs, Z. Anorg. Allg. Chem. 1998, 624, 411-418.

[39] B. M. Powell, K. M. Heal, B. H. Torrie, Mol. Phys. 1984, 53, 929-939.

[40] N. Bricklebank, P. J. Skabara, D. E. Hibbs, M. B. Hursthouse, K. M. Abdul Malik, J. Chem. Soc., Dalton Trans. 1999, 3007-3014.

[41] M. C. Aragoni, M. Arca, F. A. Devillanova, F. Isaia, V. Lippolis, A. Mancini, L. Pala, A. M. Z. Slawin, J. D. Woollins, Chem. Commun. 2003, 2226-2227.

[42] W. You, E. Wang, L. Xu, Z. Zhu, Y. Gu, J. Mol. Struct. 2002, 605, 41-49.

[43] M. Nissinen, S. Kiviniemi, K. Rissanen, J. Pursiainen, Cryst. Eng. Comm. 2000, 2, 102-105.

[44] J. Cosier, A. M. Glazer, J. Appl. Crystallogr. 1986, 19, 105.

[45] E. Blanc, D. Schwarzenbach, H. D. Flack, J. Appl. Cryst. 1991, 24, 1035.

[46] G. M. Sheldrick, SHELX-97, University of Göttingen, Göttingen 1997. 